\title{
Presence of human papillomavirus DNA in breast cancer: a Spanish case-control study
}

\author{
Silvia Delgado-García ${ }^{1 *}$ (D, Juan-Carlos Martínez-Escoriza ${ }^{1}$, Alfonso Alba², Tina-Aurora Martín-Bayón ${ }^{1}$, \\ Hortensia Ballester-Galiana', Gloria Peiró ${ }^{3}$, Pablo Caballero ${ }^{4}$ and Jose Ponce-Lorenzo ${ }^{5}$
}

\begin{abstract}
Background: Breast cancer is one of the most important neoplasia among women. It was recently suggested that biological agents could be the etiological cause, particularly Human Papilloma Virus (HPV). The aim of this study was to explore the presence of HPV DNA in a case-control study.

Methods: We performed our study including 251 cases (breast cancer) and 186 controls (benign breast tumors), using three different molecular techniques with PCR (GP5/GP6, CLART ${ }^{\oplus}$ and DIRECT FLOW CHIP®).

Results: HPV DNA was evidenced in $51.8 \%$ of the cases and in $26.3 \%$ of the controls $(p<0.001)$. HPV-16 was the most prevalent serotype. The odds ratio (OR) of HPV within a multivariate model, taking into account age and breastfeeding, was 4.034 .

Conclusions: Our study, with methodological rigour and a sample size not previously found in the literature, demonstrate a significant presence of HPV DNA in breast cancer samples. A possible causal relationship, or mediation or not as a cofactor, remains to be established by future studies.
\end{abstract}

Keywords: Breast cancer, Human papillomavirus, Prevalence, PCR

\section{Background}

Breast cancer is the most commonly diagnosed malignancy in women [1-3]. It is estimated that 1.7 million new cases were diagnosed in 2012, representing $11.9 \%$ of all cancers diagnosed worldwide in both genders, and $25 \%$ of those diagnosed in women [3, 4]. Breast cancer is also the most common malignancy in Spanish women, representing $29 \%$ of all female malignancies. Most of the cases are diagnosed in patients between 45 and 65 years of age [5].

Several risk factors have been cited in the literature, including patient age, gender, hormone therapy, the number of offspring, breastfeeding or different eating habits. However, there are other less well known factors that might also play an oncogenic role. Viruses are an example in this respect [6]. A number of viruses have been identified to date in breast cancer tissues. The three main viruses are Epstein Barr virus (EBV), mouse

\footnotetext{
* Correspondence: delgadogarciasilvia@gmail.com

1 Department of Obstetrics and Gynecology, University General Hospital of Alicante, c/ Pintor Baeza, 11, 03010 Alicante, Spain

Full list of author information is available at the end of the article
}

mammary tumor virus (MMTV) and human papillomavirus (HPV) [7-11]. All of them share a common feature in that they can induce the initiation and progression of cancer. Several studies $[8,9,12-19]$ have attempted to determine whether viruses in breast tissue are a casual presence (i.e., acting as "passengers") or they play an important role in carcinogenesis. The fact is that with the exception of MMTV, the rest of the viruses described in breast cancer have already been identified in other malignancies. The current published data on HPV and breast cancer are very contradictory, since the reported prevalence of HPV ranges from $0 \%$ [20-29] to $86.21 \%$ in breast cancer tissue samples [8, 10, 30-35]. Furthermore, the studies are very heterogeneous in terms of the methodology employed. A example of this is that, most of the reviewed studies involve case studies without controls. A few use case-control protocols, which offer greater methodological soundness, while only a handful evaluate statistically significant differences [9, 31, 36-43]. Moreover, the only study conducting logistic regression is that published by Sigaroodi et al. [40], though it involves a 
very wide confidence interval (1.5-130) and odds ratio $[\mathrm{OR}]=14$, which is questionable in statistical terms.

In view of the above, the investigation of viruses as breast cancer promoting factors remains subject to great controversy. The present study was designed to help clarify this issue. Specifically, we aimed to confirm the presence of HPV in a series of samples obtained from breast surgeries at the University General Hospital of Alicante (Spain), estimating the strength of the association (via [OR]) between the presence of HPV in benign breast disease and breast cancer.

\section{Methods}

A case-control study, based on a case-control ratio of $1: 1$, was performed to evaluate the presence of HPV infection in a subset of 250 embedded breast cancer tissues, as cases, and 250 embedded benign breast tissues, as controls. The estimated exposure rate (presence of HPV) was $25 \%$ and $14 \%$ in the cases and controls, respectively, with a confidence level of $95 \%$ and a statistical power of $85 \%$ in detecting OR $>2$ (computed pooling proportions of reviews or meta-analyses published until 2012) $[8,30,32]$. The samples were selected consecutively and retrospectively from the year 2012 until the calculated sample size (n) was reached. The following inclusion criteria were established: women subjected to surgical treatment due to infiltrating breast cancer and/or carcinoma in situ (cases) or benign breast disease (controls) (period 2006-2012); patients over 18 years of age; surgical specimens embedded in paraffin (stored in the tumor Biobank of our institution), in adequate conditions and sufficient amount of tissue for the purposes of the study; and the obtainment of written informed consent. The following exclusion criteria were established: males and a lack of the minimum required quality controls in the analyzed DNA samples. An ad-hoc case report form was created to record demographic, histopathological and virological information. Data were anonymized in compliance with the protection of personal data code.

\section{Immunohistochemical and in SITU hybridization analysis}

After surgical excision (either mastectomy or tumorectomy), specimens were fixed in $10 \%$ formalin solution and subsequently embedded in paraffin. For the histological study, sections measuring $4 \mu \mathrm{m}$ in thickness were obtained and stained with hematoxylin-eosin. The expressions of estrogen receptor (ER), progesterone receptor (PgR), human epidermal growth factor receptor (HER2) and Ki-67 were determined by immunohistochemistry (IHC) using standard techniques, with commercial antibodies and conditions following the instructions of the manufacturer on an automated basis (Techmate-500). The following antibodies were used: ER
(Dako, clone 1D5, dilution 1:50), PgR (Dako, clone PgR 636, dilution 1:50), Ki-67 (Dako, clone MIB-1, dilution 1:100) and HercepTest ${ }^{\circ}$ (Dako). The study of the ER and PR expression levels was made evaluating the percentage of stained tumor cell nuclei and the intensity of staining according to the guidelines of the American Society of Clinical Oncology (2010) [44] and of the American College of Pathologists. Positive status was considered for $>1 \%$ ER or PR. HER2 status in turn was determined according to the recommendations of the American Society of Clinical Oncology (2007) and guidelines of the American College of Pathologists [45]. Immunohistochemical positive was defined as staining $3+$ (uniform, membrane staining intensity $>10 \%$ of the infiltrating tumor cells), while negative was defined as staining 0 or $1+$. ERBB2 gene status was confirmed by fluorescence in situ hybridization (FISH) (Dako phar$\left.\mathrm{maDx}^{\mathrm{m}}\right)$ or chromogenic in situ hybridization $(\mathrm{CISH})$ (Spot light ${ }^{\mathrm{tw}}$; Zymed) in equivocal cases $(2+$ and $<10 \% 3+$ cells). Ki67 was semiquantitatively assessed in at least three high-magnification fields $[\times 400]$ including hot-spots areas, and classified as low $(<14 \%)$ versus high $(>14 \%)$ (nuclei) $[44,45]$.

\section{Viral DNA sequences extraction}

The search for viral DNA was carried out at the Instituto de Estudios Celulares y Moleculares (Lugo, Spain), due to its well demonstrated experience in molecular and genetic studies. Sections measuring $10 \mu \mathrm{m}$ in thickness were obtained from the tumor area of the paraffin block for the identification of viral DNA. In order to avoid crosscontamination between samples, special care was taken in handling and sectioning the samples. The following procedure was carried out:

1. Deparaffinization: Four paraffin-embedded tissue sections were placed in a $1.5-\mathrm{ml}$ tube, followed by the addition of $1 \mathrm{ml}$ of xylene and vortexing for $10 \mathrm{~s}$. After incubation at room temperature during $10 \mathrm{~min}$, centrifugation was carried out at $13,000 \mathrm{rpm}$ for $5 \mathrm{~min}$. The supernatant was discarded and $1 \mathrm{ml}$ of absolute ethanol was added, followed by centrifugation at 13,000 rpm for $2 \mathrm{~min}$. The supernatant was then again discarded. This ethanol washing step was repeated one more time. Lastly, the sample was incubated at $56{ }^{\circ} \mathrm{C}$ during $15 \mathrm{~min}$ to eliminate the traces of ethanol.

2. DNA extraction: After completion of the deparaffinization process we added $500 \mu \mathrm{l}$ of lysis buffer (10 mM Tris pH 8, $100 \mathrm{mM} \mathrm{NaCl}, 25 \mathrm{mM}$ EDTA, $0.5 \%$ sodium dodecylsulfate [SDS]) and $10 \mu \mathrm{l}$ of proteinase $\mathrm{K}(20 \mathrm{mg} / \mathrm{ml})$, followed by vortexing and incubation in a shaking water bath at $56{ }^{\circ} \mathrm{C}$ overnight. Proteinase $\mathrm{K}$ was inactivated by 
incubation at $95{ }^{\circ} \mathrm{C}$ during $10 \mathrm{~min}$. An equivalent volume of chloroform: isoamyl alcohol $(24: 1 \mathrm{v} / \mathrm{v})$ was added, shaking gently by inverting the tube and then centrifuging at 10,000 rpm for $10 \mathrm{~min}$. The upper aqueous phase was transferred to a new microcentrifugation tube, and 0.2 volumes of ammonium acetate $10 \mathrm{M}$ were added. The DNA was precipitated by adding two volumes of absolute ethanol, followed by vortexing for $5 \mathrm{~s}$, incubation at $-20{ }^{\circ} \mathrm{C}$ during $30 \mathrm{~min}$ and centrifugation at $10,000 \mathrm{rpm}$ for $20 \mathrm{~min}$. The supernatant was discarded and the precipitate was washed with $500 \mu \mathrm{l}$ of cold $70 \%$ ethanol, followed by centrifugation for $5 \mathrm{~min}$ at 10,000 rpm. After discarding the supernatant again, the precipitate was dried at room temperature during $20 \mathrm{~min}$. The DNA was finally resuspended in $50 \mu$ of Tris-EDTA solution.

3. Amount and quality of DNA: All DNA samples were analyzed using a Nanodrop 1000 kit allowing calculation of the concentration of DNA and the A260/A280 and A260/A230 ratios, which indicate the purity of the molecule.

4. DNA amplification capacity: The integrity of the extracted DNA was evaluated by polymerase chain reaction (PCR) amplification of a fragment of the methylenetetrahydrofolate reductase (MTHFR) gene.

5. Detection and genotyping of HPV: The samples were subjected to three different HPV detection methods:

1. - Amplification of the virus using the GP5+/GP6+ consensus primers: The presence of HPV DNA was evaluated by PCR using the GP5+/GP6+ primers (150 bp), which act as consensus primers for the HPV L1 gene. The PCR reaction was carried out with $5 \mu \mathrm{l}$ of DNA in a total reaction volume of $50 \mu \mathrm{l}$ containing $25 \mu \mathrm{l}$ of DreamTaq Green PCR Master Mix 2X (ThermoFisher Scientific), $1 \mu \mathrm{M}$ of each primer, $0.2 \mathrm{mM}$ of DNTPs and $2 \mathrm{mM}$ of $\mathrm{MgCl}_{2}$. Amplification was performed with initial activation of the enzyme at $95{ }^{\circ} \mathrm{C}$ during two minutes, followed by 45 cycles under the following conditions: $30 \mathrm{~s}$ at $95^{\circ} \mathrm{C}$, two minutes at $40^{\circ} \mathrm{C}$ and $1.5 \mathrm{~min}$ at $72{ }^{\circ} \mathrm{C}$, with a final elongation step at $72{ }^{\circ} \mathrm{C}$ during $5 \mathrm{~min}$. The PCR products were visualized in $2 \%$ agarose gel with ethidium bromide staining using electrophoresis.

2. - CLART ${ }^{\circ}$ HPV2 amplification kit (Genomica): This kit detects the presence of the 35 HPV viruses: 6,11 , $16,18,26,31,33,35,39,40,42,43,44,45,51,52$, $53,54,56,58,59,61,62,66,68,70,71,72,73,81$, $82,83,84,85$ and 89 . Detection is carried out through amplification of a fragment of about $450 \mathrm{bp}$ within the L1 region of the virus. Five $\mu$ of DNA of each sample were subjected to PCR assay using the CLART HPV2 amplification kit (Genomica): one cycle at $95{ }^{\circ} \mathrm{C}$ for $5 \mathrm{~min}, 40$ cycles at $94{ }^{\circ} \mathrm{C}$ for $30 \mathrm{~s} /$ $55^{\circ} \mathrm{C}$ for $60 \mathrm{~s} / 72{ }^{\circ} \mathrm{C}$ for $90 \mathrm{~s}$, and one cycle at $72{ }^{\circ} \mathrm{C}$ for $8 \mathrm{~min}$. The PCR products were denaturalized at $95^{\circ} \mathrm{C}$ during $10 \mathrm{~min}$ and placed in a container with ice. Hybridization was performed using $10 \mu \mathrm{l}$ of the denaturalized PCR product in the CLART microarray, followed by examination according to the instructions of the manufacturer.

3. - HPV Direct Flow CHIP kit (Master Diagnostica): The technique is based on amplification of the viral DNA followed by membrane flow-through reverse dot blot hybridization of the amplified products. Types of HPV detected: High oncogenic risk $(16,18,26,31,33,35,39,45,51,52,53,56,58,59$, $66,68,73$ and 82$)$ and low oncogenic risk $(6,11,40$, 42, 43, 44, 54, 55, 61, 62, 67, 69, 70, 71, 72, 81, 84 and 89 (CP6108)). Six $\mu$ l of purified DNA of each sample were amplified by PCR under the following conditions: one cycle at $98^{\circ} \mathrm{C}$ for 5 min, 5 cycles at $98{ }^{\circ} \mathrm{C}$ for $5 \mathrm{~s} / 42{ }^{\circ} \mathrm{C}$ for $5 \mathrm{~s} / 72{ }^{\circ} \mathrm{C}$ for $10 \mathrm{~s}, 45$ cycles at $98{ }^{\circ} \mathrm{C}$ for $5 \mathrm{~s} / 60{ }^{\circ} \mathrm{C}$ for $5 \mathrm{~s} / 72{ }^{\circ} \mathrm{C}$ for $10 \mathrm{~s}$, and one cycle at $72{ }^{\circ} \mathrm{C}$ for one minute. The samples were kept in refrigerated tubes $\left(8-10^{\circ} \mathrm{C}\right)$ until processing. The PCR products were denaturalized by heating to $95{ }^{\circ} \mathrm{C}$ for $5 \mathrm{~min}$ (in a thermocycler) and then quickly cooled in ice for two minutes.

Hybridization and interpretation of the results were carried out following the instructions of the kit manufacturer. All samples were analyzed using the three techniques above mentioned to increase test sensitivity. A positive result was defined when at least two of the three methods detected the presence of HPV. If the results proved questionable, or in the event of insufficient material, the sample was discarded to the effects of analysis. Likewise, all the samples passed the cellular DNA test (internal control), to avoid possible false-negative results. As negative control we included "HPV free DNA" and as positive control a HPV plasmid mixture with all target types. Contradictory results were obtained in only 6 samples, and these were therefore considered lost.

The following variables were recorded: patient age, personal breast cancer history, smoker, number of children, breastfeeding, age at menopause, history of cervical disease, adjuvant therapy, histopathological of the tumor (tumor size, grade, stage, number of positive lymph nodes, local/ distant metastasis), immunohistochemical characteristics (ER, PgR, HER2, Ki67), and the detected HPV serotype.

\section{Data analysis}

A descriptive analysis was made of all the study variables. In order to analyze the homogeneity of the two 
groups (cases and controls) with respect to those variables which the literature describes as being associated to breast cancer, a calculation was made of the means of the quantitative variables for both groups and comparisons were established using the Student $t$-test. In the case of the qualitative variables, cross tables were generated, and associations were analyzed using the ChiSquared test. In addition, any variables (qualitative or quantitative) found to be non-homogeneous in the cases and controls were taken into account when explaining the lack of homogeneity for the other variables. To this effect, we calculated the strength of the association between the cases and controls with the variable in question, in the presence of those variables which had already demonstrated a lack of homogeneity in both groups. This process was carried out using a binary logistic regression model. In order to establish the association between HPV exposure and breast cancer, we generated a cross tables between the two variables, estimating the magnitude of the association based on calculation of the raw odds ratio (OR) for the development of breast cancer. In addition, we calculated the adjusted OR by binary logistic regression, with the corresponding $95 \%$ confidence interval (CI). A $p$-value $<0.05$ was considered statistically significant. Statistical analysis was carried out using the software package SPSS version 20.

\section{Results}

The final study included 437 samples: 251 cases (57.4\%) and 186 controls (42.6\%). (Table 1 ).

The mean age of the cases $(n=251)$ was 56.3 years, versus 40.1 years for the controls $(n=186)((p<0.001)$. Of note, the two groups are not homogeneous. A statistically significant difference of 16 years was observed between the cases and controls (Tables 1 and 2). This is justified on the basis of the natural courses of breast cancer and benign disease, and the curves corresponding to breast cancer and benign disease by ages described by the World Health Organization (WHO) [4] are analogous to those of our own study. Clearly, for ethical reasons, we cannot obtain healthy tissues on a random basis from health women without breast disease. Selection bias results if the groups are not homogeneous.
However, by using statistical tools such as binary logistic regression analysis, we can control this bias referring to the lack of homogeneity in terms of variables which presumably may be related to cancer. Furthermore, this statistical tool allows us to calculate odds ratios for each variable. After justification of the variable age, we compared the rest of the variables of the cases and controls (Table 2), and these were found to be homogeneous after logistic regression adjustment to age. This allows us to establish statistical comparisons of our primary variable, which is the presence or not of viral DNA.

Data obtained to determine the presence of HPV in breast cancer tissue samples and establish the comparison with the samples corresponding to benign breast tissue, were analyzed using the Chi-Squared test. Using this test, the HPV exposure rate among the cases was significantly higher (51.8\%) than the HPV exposure rate in the controls $(26.3 \%)(p<0.001)$ (Table 3).

The raw OR was 3.0 (CI 95\%: 2.0-4.5). On applying the binary logistic regression model to control for confounding variables, the OR assigned to HPV was seen to be 4.034 (CI 95\%: 2.213-7.352) (Table 4), which means a higher risk of suffering cancer in the presence of HPV, taking into account patient age and breastfeeding. The rest of the confounding variables showed no significance in the binary logistic regression model (all $p=$ non significant).

The mean tumor size in HPV-positive tumors was larger $(30.53 \mathrm{~mm})$ than in those HPV-negative $(28.37 \mathrm{~mm})$, though the difference failed to reach statistical significance $(p=0.395)$. None of the analyzed histopathological variables showed a statistically significant association with the presence of HPV (Table 5, at the end).

Regarding the association of the different immunohistochemical subtypes with the presence or not of HPV, the presence of HPV is related to the luminal B phenotypes (particularly HER2-negative), while in contrast the triple negative and luminal A phenotypes are more related to the absence of HPV. However, this relationship is not statistically significant $(p=0.055)$ (Table 5$)$.

Within the global sample, $47 \%$ of the cases $(n=55)$ and $61.2 \%$ of the controls $(n=30)$ were infected by

Table 1 Clinical characteristics of breast cancer tissues (cases) and breast benign diseases (controls)

\begin{tabular}{|c|c|c|c|c|}
\hline & \multicolumn{2}{|c|}{ Cases } & \multicolumn{2}{|c|}{ Controls } \\
\hline & $N$ & Mean (Cl 95\%) & $N$ & Mean (Cl 95\%) \\
\hline$\overline{\mathrm{Age}^{* *}}$ & 251 & $56.32(54.76-57.88)$ & 186 & $40.08(38.3-41.86)$ \\
\hline Number of children & 250 & $1.92(1.76-2.09)$ & 185 & $1.3(1.11-1.5)$ \\
\hline Breastfeeding duration (months) & 191 & $8.65(7.16-10.15)$ & 115 & $9.42(6.92-11.92)$ \\
\hline Age at menopause & 140 & $48.89(48.16-49.61)$ & 36 & $48(46.47-49.53)$ \\
\hline Tumor size (mm) & 249 & 29.49 (26.99-31.99) & 98 & $31.83(29.31-34.34)$ \\
\hline
\end{tabular}

Cl 95\% Confidence Interval 95\%, ** Statistic Signification $<0.01$ 
Table 2 Frequency of cases and controls by clinicopathological factors

\begin{tabular}{|c|c|c|c|c|c|c|c|}
\hline & & Number & Cases $n(\%)$ & Controls $n(\%)$ & $\begin{array}{l}p \text {-value } \\
\text { (p-value adjusting for age) }\end{array}$ & OR (Cl 95\%) & AOR by Age (Cl 95\%) \\
\hline \multirow[t]{4}{*}{ Age (years) } & $<40$ & 109 & $19(7.6)$ & $90(48.4)$ & $<0.001$ & 1 & - \\
\hline & $40-49$ & 119 & $60(23.9)$ & $59(31.7)$ & & $4.8(2.6-8.9)^{* *}$ & - \\
\hline & $50-59$ & 97 & $72(28.7)$ & $25(13.4)$ & & $13.6(7.0-26.7)^{* *}$ & - \\
\hline & $\geq 60$ & 112 & $100(39.8)$ & $12(6.5)$ & & $39.5(18.2-85.8)^{* *}$ & - \\
\hline \multirow[t]{2}{*}{ Smoker } & Yes & 196 & $93(37.7)$ & $103(56.3)$ & $\begin{array}{l}<0.001 \\
(0.446)\end{array}$ & $0.5(0.3-0.7)^{* *}$ & $0.8(0.5-1.2)$ \\
\hline & No & 234 & $154(62.3)$ & $80(43.7)$ & & 1 & 1 \\
\hline \multirow[t]{2}{*}{ Personal BC history } & Yes & 13 & $12(4.8)$ & $1(0.5)$ & $\begin{array}{l}0.009 \\
(0.086)\end{array}$ & $9.3(1.2-72.1)^{* *}$ & $7.0(0.8-64.7)$ \\
\hline & No & 424 & $239(95.2)$ & $185(99.5)$ & & 1 & 1 \\
\hline \multirow[t]{2}{*}{ Number of children } & $1+$ & 326 & $205(81.7)$ & $121(65.1)$ & $\begin{array}{l}<0.001 \\
(0.465)\end{array}$ & $2.4(1.5-3.7)^{* *}$ & $1.0(0.6-1.8)$ \\
\hline & None & 111 & $46(18.3)$ & $65(34.9)$ & & 1 & 1 \\
\hline \multirow[t]{2}{*}{ Breastfeeding (months) } & $12+$ & 81 & $52(27.2)$ & $29(25.2)$ & $\begin{array}{l}0.789 \\
(0.139)\end{array}$ & $1.1(0.6-1.9)$ & $0.8(0.4-1.5)$ \\
\hline & $0-11$ & 170 & $139(72.8)$ & $86(74.8)$ & & 1 & 1 \\
\hline \multirow[t]{2}{*}{ Menopausial status } & Yes & 188 & $152(62.0)$ & $36(19.7)$ & $\begin{array}{l}<0.001 \\
(0.238)\end{array}$ & $6.7(4.2-10.4)^{* *}$ & $0.7(0.3-1.6)$ \\
\hline & No & 240 & $93(38.0)$ & $147(80.3)$ & & 1 & 1 \\
\hline \multirow[t]{3}{*}{ Age at menopause (years) } & $\geq 54$ & 25 & $24(15.8)$ & $1(2.8)$ & $\begin{array}{l}0.012 \\
(0.179)\end{array}$ & $18(1.9-173)^{* *}$ & $7.5(0.7-82.6)$ \\
\hline & $42-53$ & 149 & $120(78.9)$ & $29(80.6)^{*}$ & & $3.1(0.9-9.6)^{*}$ & $1.8(0.5-6.9)$ \\
\hline & $\leq 41$ & 14 & $8(5.3)$ & $6(16.7)$ & & 1 & 1 \\
\hline \multirow[t]{2}{*}{ History of cervical diseases } & No & 302 & $156(95.7)$ & $146(91.8)$ & $\begin{array}{l}0.171 \\
(0.288)\end{array}$ & $1.9(0.8-5.1)$ & $1.7(0.6-4.8)$ \\
\hline & Yes & 20 & $7(4.3)$ & $13(8.2)$ & & 1 & 1 \\
\hline
\end{tabular}

OR Odd Ratio, AOR Adjusted Odd Ratio, BC Breast Cancer, Cl 95\% Confidence Interval 95\%, * Statistic signification $<0.05$, ** Statistic Signification $<0.01$

more than one HPV serotype. In other words, coinfection by more than one viral serotype was observed in 85 samples. With regard to the identified serotypes, in the 179 samples (130 cases and 49 controls) with the presence of viral DNA, we identified 16 different high risk serotypes and 11 low risk serotypes. Figures 1 and 2 show HPV serotype 16 to be the most frequent high risk serotype in both the cases and the controls, followed by HPV-89 (Fig. 3).

\section{Discussion}

Band in 1991 [46] were the first to postulate that HPV might be implicated in breast cancer. These authors suggested that HPV-16/HPV-18 could immortalize the

Table 3 Frequency of HPV-positive by cases and controls

\begin{tabular}{|c|c|c|c|c|c|c|}
\hline & \multicolumn{2}{|c|}{ Cases $(n=251)$} & \multicolumn{2}{|c|}{ Controls $(n=186)$} & \multirow{2}{*}{$\begin{array}{l}\text { OR (Cl } \\
95 \%)\end{array}$} \\
\hline & & $\bar{N}$ & $\%$ & $\bar{N}$ & $\%$ & \\
\hline \multirow[t]{2}{*}{ HPV } & $\mathrm{HPV}+$ & 130 & $51.8 \%$ & 49 & $26.3 \%$ & $3.0^{* *}$ \\
\hline & HPV- & 121 & $48.2 \%$ & 137 & $73.7 \%$ & $(2.0-4.5)$ \\
\hline
\end{tabular}

** Statistic Signification $<0.01$, Cl 95\% Confidence Interval 95\% epithelial cells of normal mammary gland tissue through the inhibition of apoptosis. Shortly after, in 1992, Di Lonardo [47] by PCR techniques confirmed the presence of HPV-16 in $29.4 \%$ of 17 breast cancer samples supporting a potential relationship between HPV and breast carcinoma.

In the current study, the presence of HPV was shown in $51.8 \%$ of the cases and $26.3 \%$ of the controls. Of note, these results are higher than the prevalence described by some meta-analyses [30], in which HPV was found to be present in $23 \%$ of the cases and in $12.9 \%$ of the controls, although the difference here was also statistically

Table 4 Binary logistic regression model to control for confounding variables in a case-control study

\begin{tabular}{lllll}
\hline & Coef. B & Sig. & OR. & Cl. 95\% \\
\hline HPV & 1.395 & $<0.001$ & 4.034 & $2.213-7.352$ \\
Age & 0.11 & $<0.001$ & 1.116 & $1.084-1.15$ \\
Breastfeeding & -0.032 & 0.022 & 0.969 & $0.943-0.996$ \\
Constant & -5.274 & $<0.001$ & 0.005 &
\end{tabular}

Coef. B. Value of the coefficient in the logistic regression model. Sig Statistic signification, OR Odd Ratio, Cl 95\% Confidence Interval 95\% 
Table 5 Frequency of HPV-positive cases (Breast cancer) by clinicopathological factors

\begin{tabular}{|c|c|c|c|c|c|c|c|c|}
\hline & & \multirow[t]{2}{*}{ Number } & \multicolumn{2}{|c|}{$\mathrm{HPV}+$} & \multicolumn{2}{|c|}{ HPV- } & \multirow[t]{2}{*}{$P^{*}$} & \multirow[t]{2}{*}{ OR (Cl 95\%) } \\
\hline & & & $n$ & $\%$ & $n$ & $\%$ & & \\
\hline \multirow[t]{2}{*}{ Lymph vascular invasion } & Yes & 43 & 23 & $17.7 \%$ & 20 & $16.5 \%$ & 0.868 & $1.1(0.6-2.1)$ \\
\hline & No & 208 & 107 & $82.3 \%$ & 101 & $83.5 \%$ & & 1 \\
\hline \multirow[t]{2}{*}{ Lymph node metastasis } & Yes & 104 & 52 & $40.0 \%$ & 52 & $43.0 \%$ & 0.701 & $0.9(0.5-1.5)$ \\
\hline & No & 147 & 78 & $60.0 \%$ & 69 & $57.0 \%$ & & 1 \\
\hline \multirow[t]{2}{*}{ Metastasis } & Yes & 10 & 6 & $4.6 \%$ & 4 & $3.3 \%$ & 0.751 & $1.4(0.4-5.1)$ \\
\hline & No & 241 & 124 & $95.4 \%$ & 117 & $96.7 \%$ & & 1 \\
\hline \multirow[t]{2}{*}{ Neoadjuvant therapy } & Yes & 33 & 16 & $12.3 \%$ & 17 & $14.0 \%$ & 0.712 & $0.9(0.4-1.8)$ \\
\hline & No & 218 & 114 & $87.7 \%$ & 104 & $86.0 \%$ & & 1 \\
\hline \multirow[t]{8}{*}{ Stage } & 0 & 25 & 14 & $10.9 \%$ & 11 & $9.3 \%$ & 0.724 & 1 \\
\hline & $\mathrm{IA}$ & 51 & 30 & $23.4 \%$ & 21 & $17.8 \%$ & & $1.1(0.4-2.9)$ \\
\hline & IB & 1 & 1 & $0.8 \%$ & 0 & $0.0 \%$ & & $\ldots$ \\
\hline & $\| A$ & 78 & 35 & $27.3 \%$ & 43 & $36.4 \%$ & & $0.6(0.3-1.6)$ \\
\hline & $\| \mathrm{B}$ & 45 & 25 & $19.5 \%$ & 20 & $16.9 \%$ & & $1.0(0.4-2.6)$ \\
\hline & $\| I I A$ & 32 & 15 & $11.7 \%$ & 17 & $14.4 \%$ & & $0.7(0.2-2.0)$ \\
\hline & $I I I C$ & 3 & 2 & $1.6 \%$ & 1 & $0.8 \%$ & & $1.6(0.1-20.0)$ \\
\hline & IV & 11 & 6 & $4.7 \%$ & 5 & $4.2 \%$ & & $0.9(0.2-3.9)$ \\
\hline \multirow[t]{3}{*}{ ER } & 0 & 39 & 18 & $14.1 \%$ & 21 & $17.5 \%$ & 0.407 & $2.6(0.2-27.0)$ \\
\hline & $1-19 \%$ & 4 & 1 & $0.8 \%$ & 3 & $2.5 \%$ & & 1 \\
\hline & $\geq 20 \%$ & 205 & 109 & $85.2 \%$ & 96 & $80.0 \%$ & & $3.4(0.3-33.1)$ \\
\hline \multirow[t]{3}{*}{$\mathrm{PgR}$} & 0 & 51 & 26 & $20.3 \%$ & 25 & $20.8 \%$ & 0.581 & $0.7(0.3-1.7)$ \\
\hline & $1-19 \%$ & 37 & 22 & $17.2 \%$ & 15 & $12.5 \%$ & & 1 \\
\hline & $\geq 20 \%$ & 160 & 80 & $62.5 \%$ & 80 & $66.7 \%$ & & $0.7(0.3-1.4)$ \\
\hline \multirow[t]{2}{*}{ HER2 } & + & 43 & 27 & $21.3 \%$ & 16 & $13.8 \%$ & 0.134 & $1.7(0.9-3.3)$ \\
\hline & - & 200 & 100 & $78.7 \%$ & 100 & $86.2 \%$ & & 1 \\
\hline \multirow[t]{3}{*}{$\mathrm{Ki}-67$} & $<14$ & 84 & 37 & $28.9 \%$ & 47 & $39.5 \%$ & 0.083 & 1 \\
\hline & $14-19^{*}$ & 71 & 44 & $34.4 \%$ & 27 & $22.7 \%$ & & $2.1(1.1-3.9)$ \\
\hline & $\geq 20$ & 91 & 47 & $36.7 \%$ & 45 & $37.8 \%$ & & $1.4(0.7-2.5)$ \\
\hline \multirow[t]{5}{*}{ Immunohisto-chemical subtypes } & LUMINAL A & 88 & 37 & $29.4 \%$ & 51 & $44.0 \%$ & 0.055 & $1.2(0.4-4.0)$ \\
\hline & LUMINAL B/HER2- & 83 & 50 & $39.7 \%$ & 33 & $28.4 \%$ & & $2.1(0.6-7.1)$ \\
\hline & LUMINAL B/HER2+ & 35 & 23 & $18.3 \%$ & 12 & $10.3 \%$ & & $2.7(0.7-10.4)$ \\
\hline & HER2+ & 12 & 5 & $4.0 \%$ & 7 & $6.0 \%$ & & 1 \\
\hline & TRIPLE NEGATIVE & 24 & 11 & $8.7 \%$ & 13 & $11.2 \%$ & & $1.2(0.3-4.8)$ \\
\hline
\end{tabular}

ER. PgR, HER2 OR Odd Ratio, Cl 95\% Confidence Interval 95\%, * Statistic Signification $<0.05$

significant. Nevertheless, it should be mentioned that there is a broad range of HPV-positive findings in breast cancer samples, depending on the geographical setting involved. In fact, according to Simoes [30], the prevalence in Europe is $13.4 \%$, versus $42.9 \%$ in Australia and North America. The OR calculated by this author showed HPV-positive women to have a 5.9 fold higher risk of suffering breast cancer than HPVnegative women (95\%CI: 3.36-10.67). The OR in our study was 4.034 (95\% CI: 2.213-7.352), i.e., somewhat lower than in the above study.
Regarding the implications of the presence of HPV in benign disease (26.3\% in this study), our hypothesis is that if we follow the pattern of cervical cancer and HPV, and if HPV is considered to be oncogenic for breast cancer, then it should be present both in this tissue and in some normal breasts or breasts with precancerous lesions (supposedly in lesser proportion).

In 2004, De Villiers [35] published the highest prevalence to date. She detected HPV in $86 \%$ of the cases (25/ 29 breast cancers) and in $69 \%$ of the nipple tissue samples of the same breasts used as controls (20/29). Other 


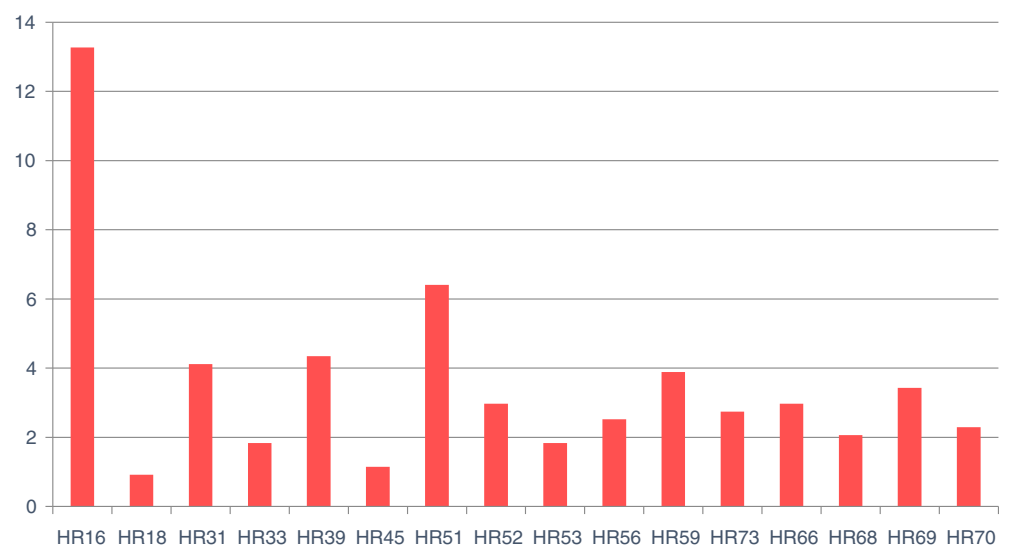

Fig. 1 Percentage of high risk (HR) viral serotypes. Percentage of high risk (HR) viral serotypes with respect to total sample size

authors [38] have also used the same cancer-affected breast as control. However, in our opinion the use of these controls is questionable from a methodological perspective, since the breasts involved presented cancer and were, therefore, not normal. Most of the published studies do not follow a precise methodology, and the screening criteria used are very heterogeneous. Some studies only consider juvenile malignancies [34], while others include inflammatory breast cancer tissues [48, 49], triple-negative tumors [50], medullary malignancies [51], metaplastic breast cancer [52], papillary lesions [20, 53], Paget's disease [54], or carcinoma in situ [9, 24, 25, $36,41,55-60]$. In addition, no standards are used in selecting the molecular technique to screen for viruses, implying the potential detection of different viral serotypes. Therefore, it is quite likely that, discrepancies among the studies are due to the factors mentioned above.

The literature published to date describes the presence of both oncological high and low risk HPV serotypes, with a broad variety of HPV subtypes. Even cutaneous variants have been reported, as in the studies of De Villiers [61] or Ong [62], who found HPV-27 or -57 , and HPV-4, respectively. Our data are consistent with the findings in the literature, according to which HPV16 is the most frequently identified serotype. However, in our study a low risk serotype not previously reported was identified, and moreover was the most prevalent among all the cases: serotype HPV-89 (Fig. 2). A possible explanation for this observations is that we used different detection methods in order to increase the range of our findings.

On the other hand, in all published studies which include cases and controls, the prevalence of HPV has been found to be higher in the cases than in the controls. In contrast, Wang et al. [63] identified HPV in one sample of 7 breast cancers and in two benign disease samples. Obviously, this study presents clear limitations in terms of sample size. Most of the published articles lack a rigorous methodological design in relation to the calculation of sample size, a fact that can weaken the results obtained. In our study, the case and control groups were designed on a 1:1 basis, and although we finally included 251 cases and 186 controls (i.e., a precise 1:1 proportion was not achieved), the statistical power was maintained.

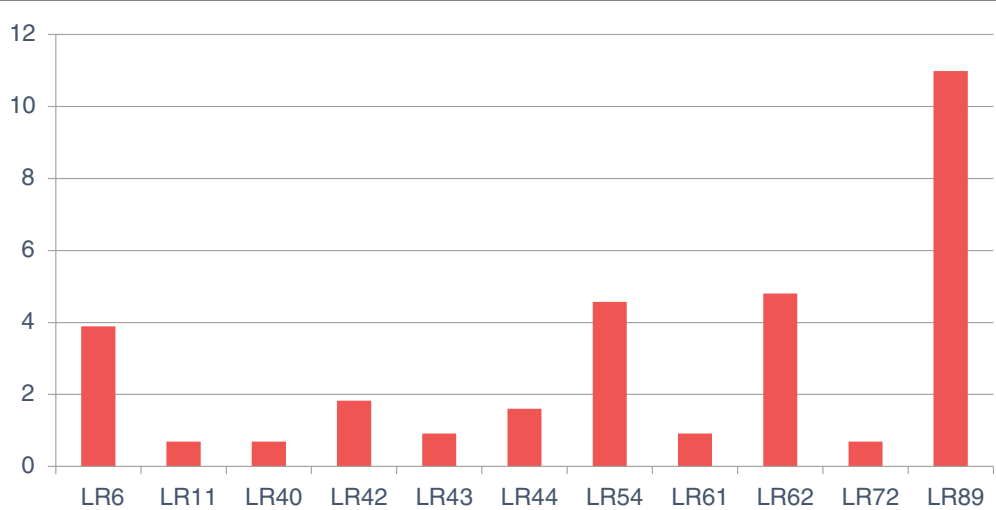

Fig. 2 Percentage of low risk (LR) viral serotypes. Percentage of low risk (LR) viral serotypes with respect to total sample size 


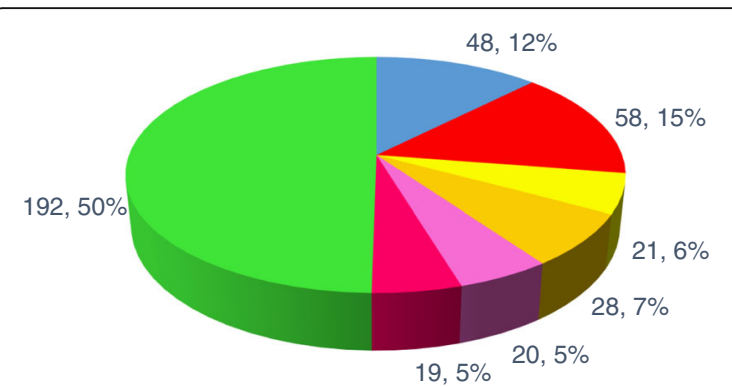

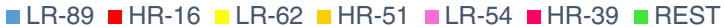

Fig. 3 Proportion of viral serotypes found more frequently in this study

To our knowledge, our study includes the larger series of samples in which HPV has been analyzed by three different validated molecular methods. Recent studies by $\mathrm{Li}$ et al. [64] (including 187 breast cancers and 92 benign tumors) and by $\mathrm{Fu}$ et al. [43] (with 169 cases and 83 controls) both in China, have shown that HPV may have a possible causal role in breast cancer pathogenesis $[65,66]$ It could be concluded that demographic and genetic characteristics may be determinant in HPVpositive breast cancer, in view of the wide range of results obtained. This is a possible explanation because there is such a different prevalence.

In our study, the presence of HPV was associated (but not significant $p$ value, $p=0.055$ ) to luminal $\mathrm{B}$ HER2-negative immunophenotype. This observation is consistent with high Ki-67 levels, since luminal B tumors present at least intermediate or high $\mathrm{Ki}-67$ expression. In this respect, among HPV-positive tumors, about $40 \%$ were luminal B/HER2-negative. In this regard, El-Shinawi et al. [49] found the expression of Ki-67 significantly higher in both (inflammatory and non-inflammatory) breast cancer with viral DNAs. In contrast, Subhawong in 2009 [67] established a similarity between the immunophenotypic characteristics of triplenegative tumors (and more specifically of basal-like tumors) and HPV-positive squamous cell carcinomas (functional loss of the retinoblastoma tumor suppressor, presence of p16 or p53 overexpression). However, in that study of 33 triple-negative breast cancers, no viral DNA was identified by in situ hybridization techniques. Other authors $[48,50]$ have also reported significant differences with triple-negative tumors. Recently, in 2015, Fernandes et al. [60] found no statistically significant association between the molecular subtypes and the presence of HPV; however the sample size was very small (10 HPV-positive samples out of a total of 24).

It is well known that luminal B tumors are ERdependent neoplasms, a condition which in turn favors the perpetuation of cervical HPV infection. Therefore, further studies are needed to confirm our results.
Emphasis should be placed on the importance of further studies to clarify the role of HPV in the carcinogenic mechanisms in breast cancer. First to clarify whether causal relationship between the virus and breast cancer actually exists. Human papillomavirus can be transmitted by skin-to-skin contact, as well as by sexual activity. Sexual transmission is the generally accepted transmission route, though it is not the only route, since transmission could occur by hand from the female perineum to the breast, wich could occur during sexual activity or even showering or bathing $[8,11,68-70]$. In an attempt to identify the possible origin of HPV in the breast, a number of authors [71-74] have explored the possible relationship between presence of the virus in the breast and cervical disease produced by HPV. Based on their studies it is not possible to conclude that HPV of the breast originates from the cervix. Further research is needed. On the other hand, De Villiers et al. [61] demonstrated the presence of HPV in $69 \%$ of the nipples of breasts with cancer. This as early as 2004 already suggested that HPV could gain access to the breast tissues through the nipple. Based on this idea, some investigators postulated breast milk as one of the main transmission routes of the virus, with the breast epithelial cells as the site of latent infection $[9,10]$.

Accordingly, breast epithelial cells that lose cell proliferation control are more susceptible to HPV infection. This loss of control is one of the first steps in breast carcinogenesis. Human papillomavirus infection in women takes place through contact by the hands or body fluids (e.g. breast milk...), with microfissures in the nipple serving as entry points for HPV. Errors may occur in the normal cell repair process, and this in combination with other cofactors can favour cell immortalization. Some of these immortal cells can be infected with viral DNA episomes or integrated DNA. The possible mechanisms whereby HPV intervenes in breast carcinogenesis may be the same as in the anogenital setting [42], through E6 and E7, though the viral load found in the breast is much lower.

The presence of HPV might also provide a new target allowing individualized patient treatment. The possibility of including antiviral agents as part of the strategy for the prevention (vaccines) $[18,75]$ and treatment of breast cancer could be a reality in the future, as it is currently done in other cancers, such as hepatocellular carcinoma or Kaposi's sarcoma.

In contrast to other viruses with known neoplastic transformation potential, HPV can be defined as having "indirect" oncogenic capacity. The so-called "viral transforming genes", which synthesize proteins involved in the inhibition and degradation of key mediators in cell division and the control of apoptosis (p53 and $\mathrm{Rb}$ ), promote cellular susceptibility to neoplastic transformation 
due to the impossibility of repairing DNA errors induced by a series of intrinsic or extrinsic factors during cell division. The oncogenic action is therefore indirect, since there is no direct intervention as host gene promoters, regulators or inhibitors. Oncogenic papillomaviruses intervene in the cell division phase, promoting inhibition of the cellular repair capacity. This phenomenon, and the associated environmental circumstances, lead to the accumulation of errors, often acquired on a random basis (so called clastogenic effect), with a phenotype that is independent of the initial presence of the virus. No differences would therefore be expected in the phenotypic evolution of tumors induced by HPV or potentially induced by some other type of genetic-environmental event.

\section{Conclusions}

In conclusion, this study of 251 cases and 186 controls has evidenced HPV DNA in 51.8\% of the cases (breast cancer specimens) and in $26.3 \%$ of the controls (benign disease). Furthermore, the OR corresponding to HPV within the multivariate model, taking age and lactation into account, is 4.034. We have not been able to establish a significant relationship between the presence of viral DNA and the immunohistochemical subtypes. Nevertheless, there is a certain tendency to correlate the presence of HPV to the HER2- luminal B subtype ( $p=0.055)$. In concordance with existing literature, the most prevalent serotype was found to be HPV-16. The strongly discrepant results in the literature are explained by the great methodological diversity found among the different studies. Our study, with methodological rigour and a sample size not previously found in the literature, demonstrate a significant presence of HPV DNA in the breast cancer samples. A possible causal relationship, or mediation or not as a cofactor, remains to be established by future studies.

\section{Abbreviations}

Cl: Confidence interval; ER: Estrogen receptor; FDA: Food and Drug Administration; FISH: Fluorescence in situ hybridization; HER2: Human epidermal growth factor receptor 2; HPV: Human papillomavirus; PCR: Polymerase chain reaction; PgR: Progesterone receptor

\section{Acknowledgments}

The authors thank the breast cancer and benign diseases patients of the University General Hospital of Alicante who donated their tissues for research. Thanks to Sandra and Dra. Alenda of Alicante's Biobank. Thanks to Dr. Sánchez which helps us in the initial study design. Thanks to Cristina Suárez for supervising the final version of the manuscript.

\section{Funding}

This study did not receive any extra-institutional funding.

\section{Availability of data and materials}

The dataset supporting the conclusions of this article is available at request from the corresponding author. These datasets are in the process of further analysis and research.

\section{Authors' contributions}

Conception and design: SDG, JCME. Acquisition of data: SDG, AA. Analysis of data: SDG, JCME, PC. Interpretation of data: SDG, JCME, AA, TAMB, HBG, GP, PC, JJPL. All authors contributed to manuscript draft and the revisions.

All authors read and approved the final manuscript.

\section{Competing interests}

The authors declare that they have no competing interests.

\section{Consent for publication}

Not applicable.

\section{Ethics approval and consent to participate}

All data linkage was performed by researchers. Patient written consent was required for this study. The present study was carried out in strict abidance with the basic ethical principles of the Declaration of Helsinki and Spanish Organic Act 15/1999 referred to personal data protection. In addition, the study was approved by both, the Clinical Research Ethics Committee and the Managing Board of the University General Hospital of Alicante and Biobank.

\section{Publisher's Note}

Springer Nature remains neutral with regard to jurisdictional claims in published maps and institutional affiliations.

\section{Author details}

'Department of Obstetrics and Gynecology, University General Hospital of Alicante, c/ Pintor Baeza, 11, 03010 Alicante, Spain. ${ }^{2}$ Department of Genetics, Institute of Cellular and Molecular Studies, Lugo, Spain. ${ }^{3}$ Department of Pathology, University General Hospital of Alicante, Institute of Sanitary and Biomedical Research of Alicante (ISABIAL), Alicante, Spain. ${ }^{4}$ Department of Community Nursing, Preventive Medicine and Public Health and History of Science, University of Alicante, Alicante, Spain. ${ }^{5}$ Department of Medical Oncology, University General Hospital of Alicante, Alicante, Spain.

Received: 13 June 2016 Accepted: 1 May 2017

Published online: 08 May 2017

\section{References}

1. Organización Mundial de la Salud. Cáncer de mama: Prevención y Control. 2015; Available at: http://www.who.int/topics/cancer/breastcancer/es/ index1.html:

2. Ferlay J, Soerjomataram I, Ervik M, Dikshit R, Eser S, Mathers C, Rebelo M, Parkin DM, Forman D, Bray F. Cancer incidence and mortality patterns in Europe: estimates for 40 countries in 2012. Eur J Cancer. 2013;49(6):1374-403.

3. Ferlay J, Soerjomataram I, Dikshit R, Eser S, Mathers C, Rebelo M, et al. Cancer incidence and mortality worldwide: sources, methods and major patterns in GLOBOCAN 2012. Int J Cancer. 2015:136(5):E359-86.

4. Lakhani, SR. (Ed.). (2012). WHO classification of tumours of the breast. International Agency for Research on Cancer.

5. Las Cifras del Cáncer en España 2014. Sociedad Española de Oncología Médica 2014; Available at: www.seom.org.

6. Lawson JS. Do viruses cause breast cancer? Cancer Epidemiology: Springer; 2009. p. 421-38.

7. Amarante MK, Watanabe MAE. The possible involvement of virus in breast cancer. J Cancer Res Clin Oncol. 2009;135(3):329-37.

8. Joshi D, Buehring GC. Are viruses associated with human breast cancer? Scrutinizing the molecular evidence. Breast Cancer Res Treat. 2012;135(1):1-15.

9. Glenn WK, Heng B, Delprado W, lacopetta B, Whitaker NJ, Lawson JS. Epstein-Barr virus, human papillomavirus and mouse mammary tumour virus as multiple viruses in breast cancer. PLoS One. 2012;7(11):e48788.

10. Alibek K, Kakpenova A, Mussabekova A, Sypabekova M, Karatayeva N. Role of viruses in the development of breast cancer. Infect Agent Cancer. 2013;8(1):32-7.

11. Lawson JS, Günzburg WH, Whitaker NJ. Viruses and human breast cancer. Future Microbiol. 2006;1(1):33-51.

12. Tsai J, Tsai $C$, Cheng M, Lin $S, X U$ F, Yang C. Association of viral factors with non-familial breast cancer in Taiwan by comparison with non-cancerous, fibroadenoma, and thyroid tumor tissues. J Med Virol. 2005;75(2):276-81.

13. Liu Y, Klimberg VS, Andrews NR, Hicks CR, Peng H, Chiriva-Internati M, et al. Human papillomavirus DNA is present in a subset of unselected breast cancers. J Hum Virol. 2001;4(6):329-34. 
14. Pereira Suarez A, Lorenzetti M, González Lucano R, Cohen M, Gass H, Martínez Vazquez $\mathrm{P}$, et al. Presence of human papilloma virus in a series of breast carcinoma from Argentina. PLoS One. 2013;8(4):e61613.

15. Aguayo F, Khan N, Koriyama C, González C, Ampuero S, Padilla O, et al. Human papillomavirus and Epstein-Barr virus infections in breast cancer from chile. Infect Agent Cancer. 2011;23(6):1.

16. De Paoli P, Carbone A. Carcinogenic viruses and solid cancers without sufficient evidence of causal association. Int J Cancer. 2013;133(7):1517-29.

17. Bae JM. Two hypotheses of dense breasts and viral infection for explaining incidence of breast cancer by age group in Korean women. Epidemiol Health. 2014;36:e2014020.

18. Akhter J, Ali Aziz MA, Al Ajlan A, Tulbah A, Akhtar M. Breast cancer: is there a viral connection? Adv Anat Pathol. 2014;21(5):373-81.

19. Fimereli D, Gacquer D, Fumagalli D, Salgado R, Rothe F, Larsimont D, et al. No significant viral transcription detected in whole breast cancer transcriptomes. BMC Cancer 2015 Mar 18;15:147-015-1176-2.

20. Bratthauer G, Tavassoli F, O'Leary T. Etiology of breast carcinoma: no apparent role for papillomavirus types 6/11/16/18. Pathology-Research and Practice. 1992;188(3):384-6.

21. Wrede D, Luqmani Y, Coombes R, Vousden K. Absence of HPV 16 and 18 DNA in breast cancer. Br J Cancer. 1992;65(6):891.

22. Lindel K, Forster A, Altermatt HJ, Greiner R, Gruber G. Breast cancer and human papillomavirus (HPV) infection: no evidence of a viral etiology in a group of Swiss women. Breast. 2007;16(2):172-7.

23. Vernet-Tomas M, Mena M, Alemany L, Bravo I, De Sanjose S, Nicolau P, et al. Human papillomavirus and breast cancer: no evidence of association in a spanish set of cases. Anticancer Res. 2015;35(2):851-6.

24. Kwong A, Leung CP, Shin $\mathrm{V}, \mathrm{Ng}$ EK. No evidence of human papillomavirus in patients with breast cancer in Hong Kong, southern China. ISRN Virology. 2013;2013

25. Herrera-Romano L, Fernández-Tamayo N, Gómez-Conde E, Reyes-Cardoso JM, Ortiz-Gutierrez F, Ceballos G, et al. Absence of human papillomavirus sequences in epithelial breast cancer in a Mexican female population. Med Oncol. 2012;29(3):1515-7.

26. Silva RG Jr, da Silva BB. No evidence for an association of human papillomavirus and breast carcinoma. Breast Cancer Res Treat. 2011; 125(1):261-4.

27. Hedau S, Kumar U, Hussain S, Shukla S, Pande S, Jain N, et al. Breast cancer and human papillomavirus infection: no evidence of HPV etiology of breast cancer in Indian women. BMC Cancer. 2011;11(1):27.

28. Hachana M, Ziadi S, Amara K, Toumi I, Korbi S, Trimeche M. No evidence of human papillomavirus DNA in breast carcinoma in Tunisian patients. Breast. 2010;19(6):541-4

29. de Cremoux P, Thioux M, Lebigot I, Sigal-Zafrani B, Salmon R, Sastre-Garau $X$. No evidence of human papillomavirus DNA sequences in invasive breast carcinoma. Breast Cancer Res Treat. 2008;109(1):55-8.

30. Simoes PW, Medeiros LR, Simoes Pires PD, Edelweiss MI, Rosa DD, Silva FR, et al. Prevalence of human papillomavirus in breast cancer: a systematic review. Int J Gynecol Cancer. 2012;22(3):343-7.

31. Frega A, Lorenzon L, Bononi M, De Cesare A, Ciardi A, Lombardi D, et al. Evaluation of E6 and E7 mRNA expression in HPV DNA positive breast cancer. Eur J Gynaecol Oncol. 2012;33(2):164-7.

32. Li N, Bi X, Zhang Y, Zhao P, Zheng T, Dai M. Human papillomavirus infection and sporadic breast carcinoma risk: a meta-analysis. Breast Cancer Res Treat. 2011;126(2):515-20.

33. Pollán M, García-Mendizabal MJ, Gómez BP, Aragonés N, Lope V, Pastor R, et al. Situación epidemiológica del cáncer de mama en España. Psicooncología. 2007;4(2):231-48

34. Aceto GM, Solano AR, Neuman MI, Veschi S, Morgano A, Malatesta S, et al. High-risk human papilloma virus infection, tumor pathophenotypes, and BRCA1/2 and TP53 status in juvenile breast cancer. Breast Cancer Res Treat. 2010:122(3):671-83.

35. De Villiers E, Sandstrom RE, Zur Hausen H, Buck CE. Presence of papillomavirus sequences in condylomatous lesions of the mamillae and in invasive carcinoma of the breast. Breast Cancer Res. 2005;7(1):R1-11.

36. Yu Y, Morimoto T, Sasa M, Okazaki $K$, Harada Y, Fujiwara T, et al. HPV33 DNA in premalignant and malignant breast lesions in Chinese and Japanese populations. Anticancer Res. 1999;19(6B):5057-61.

37. Damin AP, Karam R, Zettler CG, Caleffi M, Alexandre CO. Evidence for an association of human papillomavirus and breast carcinomas. Breast Cancer Res Treat. 2004;84(2):131-7.
38. Gumus M, Yumuk P, Salepci T, Aliustaoglu M, Dane F, Ekenel M, et al. HPV DNA frequency and subset analysis in human breast cancer patients' normal and tumoral tissue samples. Journal of Experimental and Clinical Cancer Research. 2006:25(4):515.

39. He Q, Zhang SQ, Chu YL, Jia XL, Wang XL. The correlations between HPV16 infection and expressions of c-erbB-2 and bcl-2 in breast carcinoma. Mol Biol Rep. 2009;36(4):807-12.

40. Sigaroodi A, Nadji SA, Naghshvar F, Nategh R, Emami H, Velayati AA. Human papillomavirus is associated with breast cancer in the north part of Iran. Sci World J. 2012;2012

41. Liang W, Wang J, Wang C, Lv Y, Gao H, Zhang K, et al. Detection of highrisk human papillomaviruses in fresh breast cancer samples using the hybrid capture 2 assay. J Med Virol. 2013;85(12):2087-92.

42. Ali SH, Al-Alwan NA, Al-Alwany SH. Detection and genotyping of human papillomavirus in breast cancer tissues from Iraqi patients. East Mediterr Health J. 2014;20(6):372-7.

43. Fu L, Wang D, Shah W, Wang Y, Zhang G, He J. Association of human papillomavirus type 58 with breast cancer in shaanxi province of China. J Med Virol. 2015;

44. Hammond ME, Hayes DF, Dowsett M, Allred DC, Hagerty KL, Badve S, et al. American Society of Clinical Oncology/College of American Pathologists guideline recommendations for immunohistochemical testing of estrogen and progesterone receptors in breast cancer. J Clin Oncol. 2010;28(16):2784-95.

45. Wolff AC, Hammond ME, Hicks DG, Dowsett M, McShane LM, Allison KH, et al. Recommendations for human epidermal growth factor receptor 2 testing in breast cancer: American Society of Clinical Oncology/College of American Pathologists clinical practice guideline update. J Clin Oncol. 2013; 31(31):3997-4013.

46. Band V, Zajchowski D, Kulesa V, Sager R. Human papilloma virus DNAs immortalize normal human mammary epithelial cells and reduce their growth factor requirements. Proc Natl Acad Sci U S A. 1990;87(1):463-7.

47. Di Lonardo A, Venuti A, Marcante ML. Human papillomavirus in breast cancer. Breast Cancer Res Treat. 1992;21(2):95-100.

48. Corbex M, Bouzbid S, Traverse-Glehen A, Aouras H, McKay-Chopin S, Carreira C, et al. Prevalence of papillomaviruses, polyomaviruses, and herpesviruses in triple-negative and inflammatory breast tumors from Algeria compared with other types of breast cancer tumors. PLoS One. 2014;9(12):e114559.

49. El-Shinawi M, Mohamed HT, Abdel-Fattah HH, Ibrahim SAA, El-Halawany MS, Nouh MA, et al. Inflammatory and non-inflammatory breast cancer: a potential role for detection of multiple viral DNAs in disease progression. Ann Surg Oncol. 2016;23(2):494-502.

50. Piana A, Sotgiu G, Muroni M, Cossu-Rocca P, Castiglia P, De Miglio M. HPV infection and triple-negative breast cancers: an Italian case-control study. Virol J. 2014:11(1):190.

51. Manzouri L, Salehi R, Shariatpanahi S. Prevalence of human papilloma virus among women with breast cancer since 2005-2009 in Isfahan. Advanced biomedical research. 2014;3

52. Herrera-Goepfert R, Vela-Chávez T, Carrillo-García A, Lizano-Soberón M, Amador-Molina A, Oñate-Ocaña LF, et al. High-risk human papillomavirus (HPV) DNA sequences in metaplastic breast carcinomas of Mexican women. BMC Cancer. 2013;13(1):445.

53. Duò D, Ghimenti C, Migliora P, Pavanelli MC, Mastracci L, Angeli G. Identification and characterization of human papillomavirus DNA sequences in Italian breast cancer patients by PCR and line probe assay reverse hybridization. Mol Med Rep. 2008;1(5):673-7.

54. Czerwenka K, Heuss F, Hosmann JW, Manavi M, Lu Y, Jelincic D, et al. Human papilloma virus DNA: a factor in the pathogenesis of mammary Paget's disease? Breast Cancer Res Treat. 1996;41(1):51-7.

55. Yasmeen A, Bismar TA, Kandouz M, Foulkes WD, Desprez P, Al MA. E6/E7 of HPV type 16 promotes cell invasion and metastasis of human breast cancer cells. Cell Cycle. 2007;6(16):2038-42

56. Akil N, Yasmeen A, Kassab A, Ghabreau L, Darnel A, Al MA. High-risk human papillomavirus infections in breast cancer in Syrian women and their association with id-1 expression: a tissue microarray study. Br J Cancer. 2008;99(3):404-7.

57. Khan N, Castillo A, Koriyama C, Kijima Y, Umekita Y, Ohi Y, et al. Human papillomavirus detected in female breast carcinomas in Japan. Br J Cancer. 2008:99(3):408-14.

58. Heng B, Glenn W, Ye Y, Tran B, Delprado W, Lutze-Mann L, et al. Human papilloma virus is associated with breast cancer. Br J Cancer. 2009;101(8): 1345-50. 
59. Baltzell K, Buehring GC, Krishnamurthy S, Kuerer H, Shen HM, Sison JD. Limited evidence of human papillomavirus on breast tissue using molecular in situ methods. Cancer. 2012;118(5):1212-20.

60. Fernandes A, Bianchi G, Feltri AP, Pérez M, Correnti M. Presence of human papillomavirus in breast cancer and its association with prognostic factors. ecancermedicalscience 2015;9.

61. De Villiers E, Fauquet C, Broker TR. Bernard H, zur Hausen H. Classification of papillomaviruses Virology. 2004;324(1):17-27.

62. Ong K, Koay ES, Putti TC. Detection of cutaneous HPV types 4 and 24 DNA sequences in breast carcinoma in Singaporean women of Asian ancestry. Pathology. 2009;41(5):436-42.

63. Wang T, Zeng X, Li W, Zhu H, Wang G, Liu X, et al. Detection and analysis of human papillomavirus (HPV) DNA in breast cancer patients by an effective method of HPV capture. PLoS One. 2014;9(3):e90343.

64. Li J, Ding J, Zhai K. Detection of human papillomavirus DNA in patients with breast tumor in China. PLoS One. 2015;10(8):e0136050.

65. Bruni L, Diaz M, Castellsague X, Ferrer E, Bosch FX, de Sanjose S. Cervical human papillomavirus prevalence in 5 continents: meta-analysis of 1 million women with normal cytological findings. J Infect Dis. 2010;202(12):1789-99.

66. Grulich AE, Vajdic CM. The epidemiology of cancers in human immunodeficiency virus infection and after organ transplantation. Semin Oncol. 2015; 42:247-57.

67. Subhawong AP, Subhawong T, Nassar H, Kouprina N, Begum S, Vang R, et al. Most basal-like breast carcinomas demonstrate the same Rb-/p16+ immunophenotype as the HPV-related poorly differentiated squamous cell carcinomas which they resemble morphologically. Am J Surg Pathol. 2009; 33(2):163-75.

68. Munoz N, Castellsagué X, de González AB, Gissmann L. HPV in the etiology of human cancer. Vaccine. 2006;24:S1-S10

69. Burchell AN, Winer RL, de Sanjosé S, Franco EL. Epidemiology and transmission dynamics of genital HPV infection. Vaccine. 2006;24:S52-61.

70. Kan C, lacopetta B, Lawson J, Whitaker N. Identification of human papillomavirus DNA gene sequences in human breast cancer. Br J Cancer. 2005;93(8):946-8.

71. Widschwendter A, Brunhuber T, Wiedemair A, Mueller-Holzner E, Marth C. Detection of human papillomavirus DNA in breast cancer of patients with cervical cancer history. J Clin Virol. 2004;31(4):292-7.

72. Hennig EM, Suo Z, Thoresen S, Holm R, Kvinnsland S, Nesland JM. Human papillomavirus 16 in breast cancer of women treated for high grade cervical intraepithelial neoplasia (CIN III). Breast Cancer Res Treat. 1999;53(2):121-35.

73. Hansen B, Nygård M, Falk R, Hofvind S. Breast cancer and ductal carcinoma in situ among women with prior squamous or glandular precancer in the cervix: a register-based study. Br J Cancer. 2012;107(9):1451-3.

74. Lv YR, Wang JL, Zhang K, Gao HD, Sun JZ, Gong YY, et al. Human papilloma viruses (HPVs) no co-existence in breast cancer and cervical cells in the same patient. Chin J Physiol. 2014;57(2):105-6.

75. Lazzeroni M, Serrano D. Potential use of vaccines in the primary prevention of breast cancer in high-risk patients. Breast Care. 2012;7(4):281-7.

\section{Submit your next manuscript to BioMed Central and we will help you at every step:}

- We accept pre-submission inquiries

- Our selector tool helps you to find the most relevant journal

- We provide round the clock customer support

- Convenient online submission

- Thorough peer review

- Inclusion in PubMed and all major indexing services

- Maximum visibility for your research

Submit your manuscript at www.biomedcentral.com/submit

) Biomed Central 